\section{Fshantsiñ}

Hugo Jamioy Juagibioy

Ndoñ quetsatajuatsënt"sná

at"sbe "so"són

jabuachán chaotsenangmen

fshantsiñ;

nÿe

sëndëbuatëmbá

chabe Mamá chabotsebobonshanam

básetemorscán.

\section{En la tierra}

Hugo Jamioy Juagibioy

No es que esté obligando

a mi hijo

a trabajos forzados

en la tierra;

solamente

le estoy enseñando

a consentir a su madre

desde pequeño.

\title{
On the Land
}

Trans. Rosalind Gill

It's not that I'm forcing

my son

into hard labour

on the land;

I'm only

teaching him

deference for his mother

from earliest childhood. 


\section{Shecuat"sëng Bet"sa"soc}

Hugo Jamioy Juagibioy

T"'sabá namna

shecuat"seng, bet"sa"soc jtsebomnán, at"sbe Taitá, echandbayan, ndocnaté jtanëngcá chacotsnam.

\section{Los pies en la cabeza}

Hugo Jamioy Juagibioy

Siempre es bueno

tener los pies en la cabeza, dice mi taita,

para que tus pasos nunca sean ciegos.

\section{Feet in Your Head}

Trans. Rosalind Gill

It is always good

to walk as if your feet are in your head, says my taita,

so the steps you take are never blind. 


\section{Ndosertanëng}

Hugo Jamioy Juagibioy

Ndás cuantsabobuatm chë ndosertaná ca ndoñ mondoben jualiamëng

librë"sangá o betiyëng.

Canÿeng y inÿeng

bat"sá y bëtscá mondëtat"sëmb.

Bëneten,

at"sbe bëtstaitá tmojuant"sabuaché

canÿe librë"sá

tmonjauyan tonday condëtat"sëmbo ca.

Ibetn

shinÿoc jotbeman

chabe cucuat"siñ

coca tsbuanach jtsebuertanayan

uaya"sac jtsichamuan

ndayá chiñ bnetsabinÿnan

\section{Analfabetas}

Hugo Jamioy Juagibioy

A quién llaman analfabetas

a los que no saben leer

los libros o la naturaleza;

unos y otros

algo y mucho saben;

durante el día

a mi abuelo le entregaron

un libro

le dijeron que no sabía nada;

por las noches

se sentaba junto al fogón

en sus manos

giraba una hoja de coca

y sus labios iban diciendo

lo que en ella miraba.

\section{Illiterates}

Trans. Rosalind Gill

Who is it they are calling illiterate, those who don't know how to read books or those who don't know how to read nature?

Well, both of those

know quite a bit;

in the daytime

someone gave my grandfather

a book

then said he knew nothing;

in the nighttime

he sat by the fire

in his hands

spinning a coca leaf

and his lips went on saying

what he saw in it. 